\title{
Interface evaluation of experimental dental adhesives with nanostructured hydroxyapatite incorporation
}

\author{
Camila Provenzi ${ }^{1}$, Vicente CB Leitune ${ }^{1}$, Fabricio M Collares ${ }^{1 *}$, Rafael Trommer $^{2}$, Carlos P Bergmann ${ }^{2}$ \\ and Susana MW Samuel ${ }^{1}$
}

\author{
* Correspondence: \\ fabricio.collares@ufrgs.br \\ ${ }^{1}$ Dental Materials Laboratory, School \\ of Dentistry, Federal University of \\ Rio Grande do Sul, Ramiro Barcelos \\ 2492, Porto Alegre, RS, Brazil \\ Full list of author information is \\ available at the end of the article
}

\begin{abstract}
The aim of this study was to evaluate the adhesive interface with dentin of an experimental adhesive resin with nanostructured hydroxyapatite addition. The organic phase of the adhesive resin was produced by mixing 50 wt.\% Bis-GMA, 25 wt.\% TEGDMA and 25 wt.\% HEMA. CQ and EDAB were added at 1 mol\% to all groups, according to the monomer moles. $\mathrm{HA}_{\text {nano }}$ was added at the following two concentrations: 0 and $2 \mathrm{wt} \%$. One commercial adhesive system was used as control. Nine lower incisor bovine teeth were used to produce interfaces of adhesive resin and dentin. Tooth slices were analysed using the following micro-Raman parameters: a $100 \mathrm{~mW}$ diode laser with $785 \mathrm{~nm}$ wavelength and spectral resolution of $\sim 3-5 \mathrm{~cm}^{-1}$. One-dimensional mapping was performed over a $150 \mu \mathrm{m}$ line across the adhesive-dentine interface at $1 \mu \mathrm{m}$ intervals using a computerized $X Y Z$ stage. These areas covered the composite resin, adhesive layer, hybrid layer, partially demineralised and un-affected dentine and were visualised and focused at $\times 500$ magnification. Raman analysis showed the penetration of experimental and commercial adhesive systems into dentin. $\mathrm{HA}_{\text {nano }}$ was observed into the hybrid layer. Based on results of the present study, is possible to observe resin and nanostructured hydroxyapatite penetration at the hybrid layer.
\end{abstract}

Keywords: Adhesive resin; Dentistry; Micro Raman

\section{空 Springer}

\section{Background}

Degradation of hybrid layer at dentin adhesive interface is a concern for long term success of restorative procedures [1]. Achievement of a more hydrolytic stable hybrid layer is a recurrent goal of adhesive systems development nowadays. Comonomer blends with higher hydrophilicity leads to a hybrid layer more prone to degradation [2,3]. Furthermore, addition of fillers to adhesive resin could increase mechanical properties and decrease long term degradation of hybrid layer. The addition of fillers reduces the amount of organic matrix in the same volume of material. Considering that fillers are less prone to degradation by hydrolysis [4], the materials with filler addition could present a decreased long term degradation.

Different types of filler have been incorporated to adhesive systems, such as $\mathrm{SiO}_{2}$ [5], $\mathrm{Ta}_{2} \mathrm{O}_{5}$ [6] and $\mathrm{Nb}_{2} \mathrm{O}_{5}$ [7] to increase its mechanical properties. However, few studies evaluated addition of apatite fillers at adhesive resin properties. Since hydroxyapatite

(C) 2014 Provenzi et al.; licensee Springer. This is an open access article distributed under the terms of the Creative Commons Attribution License (http://creativecommons.org/licenses/by/2.0), which permits unrestricted use, distribution, and reproduction in any medium, provided the original work is properly cited. 
(HA) is a biological material, its presence in hybrid layer is desirable to reconstruct the HA depleted zone after acid etching. Hydroxyapatite has been evaluated in adhesive resins in different morphologies like spherical particles [8], nanorods [9] and nanostructured hydroxyapatite $\left(\mathrm{HA}_{\text {nano }}\right)$ [10]. $\mathrm{HA}_{\text {nano }}$ addition to adhesive resin showed reliable properties in a recent published study [11]. However, the dentin/adhesive interface was not characterized regarding its infiltration. The aim of this study was to evaluate the adhesive interface with dentin of an experimental adhesive resin with nanostructured hydroxyapatite addition.

\section{Methods}

\section{Formulation}

Experimental dental adhesives were produced using bisphenol A glycol dimethacrylate (BisGMA), triethylene glycol dimethacrylate (TEGDMA), 2-hydroxyethyl methacrylate (HEMA), provided by Esstech Inc (Essington, PA, USA) and camphorquinone (CQ) and ethyl 4-dimethylaminobenzoate (EDAB) (Sigma Aldrich, USA), used without further processing. The organic phase of the adhesive was produced by mixing $50 \mathrm{wt} . \%$ Bis-GMA, 25 wt.\% TEGDMA and 25 wt.\% HEMA. CQ and EDAB were added at 1 mol\% to all groups, according to the monomer moles. Nanostructure hydroxyapatite $\left(\mathrm{HA}_{\mathrm{n} a n o}\right)$ was produced according to previous studies [10-12]. $\mathrm{HA}_{\text {nano }}$ was added at the following two concentrations: 0 and $2 \mathrm{wt} \%$. No radical scavenger was added. To improve the adhesion interface between filler particles and the matrix, $\mathrm{HA}_{\text {nano }}$ was subjected to a silanisation process with $5 \%$ of silane ( $\bigvee$ - methacryloxypropyltrimethoxysilane, Aldrich Chemical Co., Milwaukee, WI, USA) and 95\% of solvent (acetone), in weight. After the silanisation process, the particles were stored for 24 hours at $37^{\circ} \mathrm{C}$ to allow the solvent to evaporate. All components were weighed using an analytical balance (AUW220D, Shimadzu, Kyoto, Japan), mixed and ultrasonicated for 1 hour. One commercial adhesive system was used as control (Scotchbond Multipurpose Plus, 3 M ESPE, St. Paul, USA). To perform monomer photo-activation, a light-emitting diode unit (Radii Cal, SDI LTD., Bayswater, VIC, Australia) was used. An irradiation value of $1200 \mathrm{~mW} / \mathrm{cm}^{2}$ was confirmed with a digital power meter (Ophir Optronics, North Logan, UT, USA).

\section{Interface characterisation by micro-Raman}

Nine lower incisor bovine teeth were cleaned and stored in distilled water at $4^{\circ} \mathrm{C}$. The labial enamel was removed using a water-cooled, low-speed diamond saw (Low Speed Saw; Buehler, Lake Bluff, IL, USA) to expose the superficial dentin. A smear layer was produced by grinding the flat surface with a 600-grit silicon carbide $(\mathrm{SiC})$ disc under water for $30 \mathrm{~s}$. The dentin was etched with phosphoric acid 37\% (Condac 37, FGM, Joinvile, SC, Brazil) for $15 \mathrm{~s}$ and washed for an additional $15 \mathrm{~s}$. A commercial primer (Primer Scotch bond multi-purpose, 3 M ESPE, St Paul, MN, USA) was applied in all groups and the solvent was dried for $5 \mathrm{~s}$ with an air spray. Adhesive resin was applied according the experimental group and photocured for 20 seconds. A commercial composite resin (Z350, 3 M ESPE, St Paul, MN, USA) was inserted in two increments of $2 \mathrm{~mm}$ and photocured for 40 seconds each to simulate tooth restoration.

The bonded specimens were stored in distilled water in a light-proof container at $37^{\circ} \mathrm{C}$ for $24 \mathrm{~h}$. Sections ( $1 \mathrm{~mm}$ in thickness) were prepared by sectioning perpendicular to the 
flat adhesive-dentine surface, using a precision cutting machine under constant watercooling (Low Speed Saw, Buehler, Lake Bluff, IL, USA).

Micro-Raman spectroscopy was performed using a SENTERRA Raman Microscope (Bruker Optics, Ettlingen, KA, Germany). The samples were analysed using the following micro-Raman parameters: a $100 \mathrm{~mW}$ diode laser with $785 \mathrm{~nm}$ wavelength and spectral resolution of $\sim 3-5 \mathrm{~cm}^{-1}$. One-dimensional mapping was performed over a $150 \mu \mathrm{m}$ line across the adhesive-dentine interface at $1 \mu \mathrm{m}$ intervals using a computerized XYZ stage. These areas covered the composite resin, adhesive layer, hybrid layer, partially demineralized and un-affected dentine and were visualized and focused at $x 500$ magnification. Accumulation time per spectrum was 5 seconds with 2 co-additions. Post-processing was performed in Opus6.5 (Buker Optics Ettlingen, KA, Germany) and consisted of analysis with modeling, which distinguished spectral components of the adhesive and dentine. One correspondent peak of each substance was used for integration. For the hydroxyapatite, $960 \mathrm{~cm}^{-1}$ was used and for adhesive monomer, $1610 \mathrm{~cm}^{-1}$ was used.
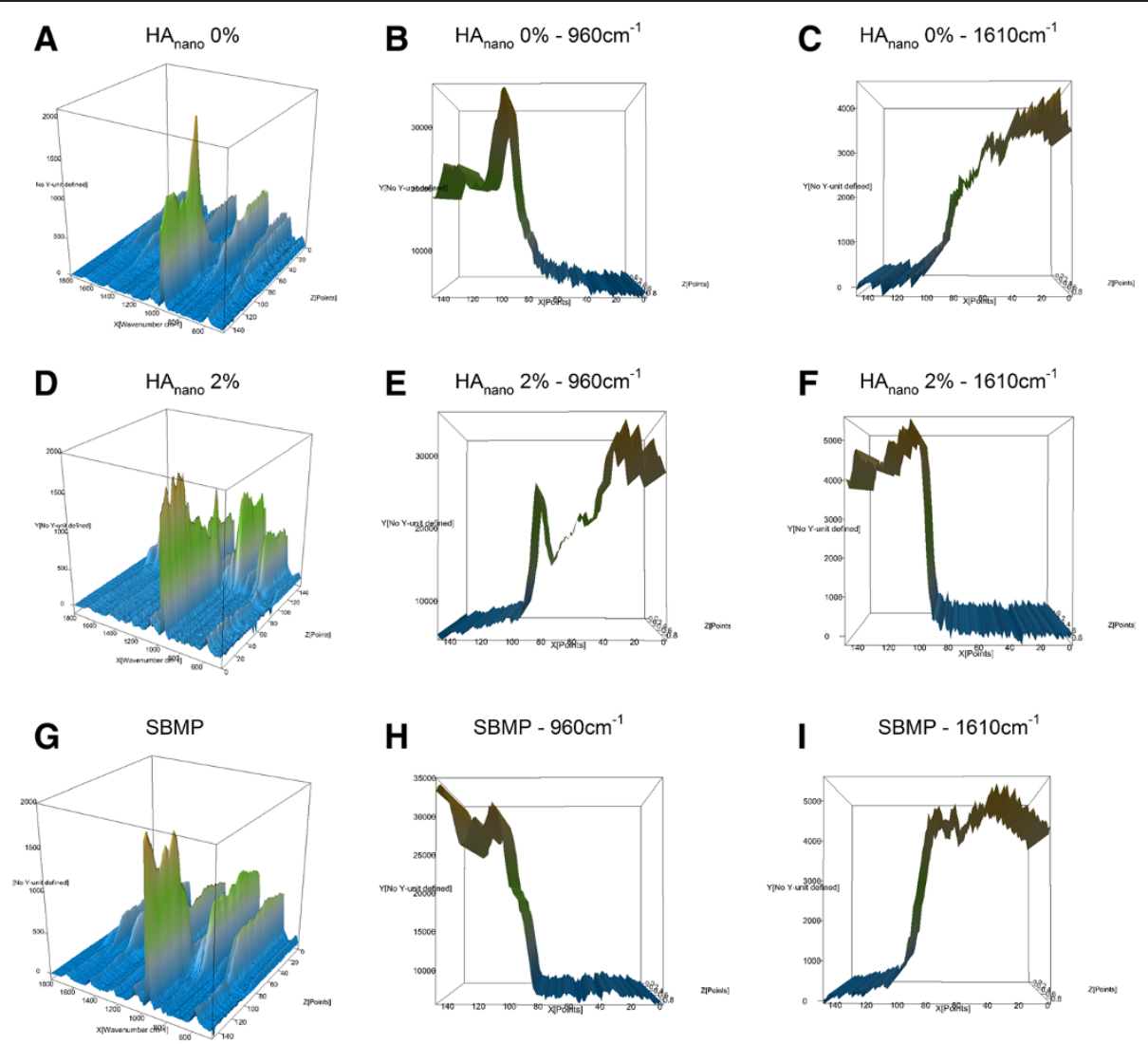

Figure 1 Representative images of interfaces dentin/resin. A, B and C represent experimental group with 0 wt\% of filler; $\mathbf{D}, \mathbf{E}$ and $\mathbf{F}$ represent experimental group with 2 wt $\%$ of nanostructure hydroxyapatite; and, G, $\mathbf{H}$ and I represent group of commercial adhesive system. Figures A, D and G show overall interface with all spectra, where the $X$ axis represents the wave number $\left(\mathrm{cm}^{-1}\right)$, the $Z$ axis represents the measurement points and the $Y$ axis represents the intensity (arbitrary unit). Figures $B, C, E, F, H$ and I represent the integration of peaks intensity, where the $Y$ axis show the intensity (arbitrary units) and the $X$ axis show the measurement points. Figures $\mathrm{B}, \mathrm{E}$ and $\mathrm{H}$ show the result of integration of $960 \mathrm{~cm}^{-1}$ peak intensity. Figures $\mathrm{C}, \mathrm{F}$ and I show the result of integration of $1610 \mathrm{~cm}^{-1}$ peak intensity. 


\section{Results and discussion}

The evaluation of interface dentin/restorative materials could illustrate the behavior of materials within the hybrid layer. In the present study, Raman analysis showed the penetration of experimental and commercial adhesive systems into dentin. Representative images of interfaces are shown in Figure 1. The presence of adhesive can be observed across the hybrid layer, and it is possible to observe the penetration of nanostructured hydroxyapatite $\left(\mathrm{HA}_{\text {nano }}\right)$ at almost the same extension of dentin demineralization (Figure 1D, E and F). The presence of inorganic fillers into adhesive layer could promote an increase the resin/dentin bond strength [11]. Inorganic fillers increase mechanical properties of adhesive resin [7] and the use of stronger polymers could result in stronger hybrid layer $[13,14]$. Complete penetration of polymer across mineral-depleted dentin is important to avoid collagen degradation, and consequently, the reduction of durability of resin/dentin bond strength [15].

The evaluation of the adhesive interface promote a more detailed understanding of relationship of different components of adhesive resin. The addition of nanofillers increase the viscosity of the resin, as shown elsewhere [16], and could difficult material penetration between demineralized collagen network. On the other hand, nanofillers are more prone to penetrate than micrometer particles. The collagen interfibrillar spaces are around $20 \mathrm{~nm}$ [17]. In the present study, the used nanostructured hydroxyapatite has a mean diameter size of $26.9 \mathrm{~nm}$, as shown elsewhere [11]. Considering the distribution of particle size, at the suggest experimental adhesive resins, could be found particles with less than $20 \mathrm{~nm}$ of diameter, allowing the penetration into collagen network spaces. In the present study, the group with $2 \mathrm{wt} \%$ hydroxyapatite addition exhibited penetration across the hybrid layer. Experimental group with $0 \mathrm{wt} \%$ of $\mathrm{HA}_{\text {nano }}$ and commercial adhesive system presented penetration of monomers across the interface (Figure 1A, B, C, G, H and I). The evaluation of a commercial adhesive could indicate the correct production of experimental adhesive (without filler - Group 0\%) and evaluate the real contribution of added filler.

In the present study, the group with incorporation of $2 \mathrm{wt} \%$ of nanostructured hydroxyapatite was evaluated since this group presented the best behaviour in other study [11]. The highest bond strength achieved by group with $2 \mathrm{wt} \%$ in other study [11] could be explained by penetration of $\mathrm{HA}_{\text {nano }}$ through the hybrid layer. Further studies should be conducted to evaluate the longitudinal bond strength and the interface behaviour after long term hydrolysis and enzymatic degradation. The present results represent an important increment at adhesive resin behavior, comparing to non filler adhesive resin.

\section{Conclusion}

Based on results of the present study it is possible to observe resin and nanostructured hydroxyapatite penetration at the hybrid layer.

Competing interests

The authors declare that they have no competing interests. 


\section{Author details}

'Dental Materials Laboratory, School of Dentistry, Federal University of Rio Grande do Sul, Ramiro Barcelos 2492, Porto Alegre, RS, Brazil. ${ }^{2}$ Ceramic Materials Laboratory, Engineering School, Federal University of Rio Grande do Sul, Osvaldo Aranha 99, Porto Alegre, RS, Brazil.

Received: 2 September 2013 Accepted: 22 October 2013

Published: 22 January 2014

\section{References}

1. De Munck J, Van Landuyt K, Peumans M, Poitevin A, Lambrechts P, Braem M, Van Meerbeek B (2005) A critical review of the durability of adhesion to tooth tissue: methods and results. J Dent Res 84(2):118-132

2. Collares FM, Ogliari FA, Zanchi CH, Petzhold CL, Piva E, Samuel SM (2011) Influence of 2-hydroxyethyl methacrylate concentration on polymer network of adhesive resin. J Adhes Dent 13(2):125-129. doi:10.3290/j.jad.a18781

3. Zanchi CH, Munchow EA, Ogliari FA, de Carvalho RV, Chersoni S, Prati C, Demarco FF, Piva E (2013) Effects of long-term water storage on the microtensile bond strength of five experimental self-etching adhesives based on surfactants rather than HEMA. Clin Oral Investig 17(3):833-839. doi:10.1007/s00784-012-0791-4

4. Ragosta G, Abbate M, Musto P (2005) Epoxy-silica particulate nanocomposites: chemical interactions, reinforcement and fracture toughness. Polymer 46:10506-10516

5. Di Hipolito V, Reis AF, Mitra SB, de Goes MF (2012) Interaction morphology and bond strength of nanofilled simplified-step adhesives to acid etched dentin. Eur J Dent 6(4):349-360

6. Schulz H, Schimmoeller B, Pratsinis SE, Salz U, Bock T (2008) Radiopaque dental adhesives: dispersion of flame-made Ta2O5/SiO2 nanoparticles in methacrylic matrices. J Dent 36(8):579-587. doi:10.1016/j.jdent.2008.04.010

7. Leitune VC, Collares FM, Takimi A, de Lima GB, Petzhold CL, Bergmann CP, Samuel SM (2013) Niobium pentoxide as a novel filler for dental adhesive resin. J Dent 41(2):106-113. doi:10.1016/j.jdent.2012.04.022

8. Zhang $Y$, Wang $Y$ (2012) Hydroxyapatite effect on photopolymerization of self-etching adhesives with different aggressiveness. J Dent 40(7):564-570. doi:10.1016/j.jdent.2012.03.005

9. Sadat-Shojai M, Atai M, Nodehi A, Khanlar LN (2010) Hydroxyapatite nanorods as novel fillers for improving the properties of dental adhesives: Synthesis and application. Dent Mater 26(5):471-482. doi:10.1016/.jental.2010.01.005

10. Trommer RM, Santos LA, Bergmann CP (2009) Nanostructured hydroxyapatite powders produced by a flame-based technique. Materials Science \& Engineering C-Materials for Biological Applications 29(6):1770-1775. doi:10.1016/j. Msec 2009.02 .006

11. Leitune VC, Collares FM, Trommer RM, Andrioli DG, Bergmann CP, Samuel SM (2013) The addition of nanostructured hydroxyapatite to an experimental adhesive resin. J Dent 41(4):321-327. doi:10.1016/j. jdent.2013.01.001

12. Collares FM, Leitune VC, Rostirolla FV, Trommer RM, Bergmann CP, Samuel SM (2012) Nanostructured hydroxyapatite as filler for methacrylate-based root canal sealers. Int Endod J 45(1):63-67. doi:10.1111/j.13652591.2011.01948x

13. Pashley DH, Ciucchi B, Sano H, Carvalho RM, Russell CM (1995) Bond strength versus dentine structure: a modelling approach. Arch Oral Biol 40(12):1109-1118.

14. Sano H, Takatsu T, Ciucchi B, Russell CM, Pashley DH (1995) Tensile properties of resin-infiltrated demineralized human dentin. J Dent Res 74(4):1093-1102

15. Pashley DH, Tay FR, Yiu C, Hashimoto M, Breschi L, Carvalho RM, Ito S (2004) Collagen degradation by host-derived enzymes during aging. J Dent Res 83(3):216-221

16. Lee JH, Um CM, Lee IB (2006) Rheological properties of resin composites according to variations in monomer and filler composition. Dent Mater 22(6):515-526

17. Tay FR, Moulding KM, Pashley DH (1999) Distribution of nanofillers from a simplified-step adhesive in acid-conditioned dentin. J Adhes Dent 1(2):103-117

doi:10.1186/2196-4351-2-2

Cite this article as: Provenzi et al:: Interface evaluation of experimental dental adhesives with nanostructured hydroxyapatite incorporation. Applied Adhesion Science 2014 2:2.

\section{Submit your manuscript to a SpringerOpen ${ }^{\circ}$ journal and benefit from:}

- Convenient online submission

- Rigorous peer review

- Immediate publication on acceptance

- Open access: articles freely available online

- High visibility within the field

- Retaining the copyright to your article

Submit your next manuscript at $\gg$ springeropen.com 